\title{
Hypercholesterolaemic valvulopathy in a young woman with heterozygous familial hypercholesterolaemia
}

\author{
Kunal Mahajan, Sanjeev Asotra, Prakash Negi
}

Department of Cardiology, Indira Gandhi Medical College, Shimla, Himachal Pradesh, India

\section{Correspondence to} Dr Kunal Mahajan, kunalmahajan442@gmail.com

Accepted 13 January 2016
CrossMark

To cite: Mahajan $K_{\text {, }}$ Asotra S, Negi P. BMJ Case Rep Published online: [please include Day Month Year] doi:10.1136/bcr-2015214254

\section{DESCRIPTION}

A 19-year-old woman presented with dyspnoea, angina and exertional syncope for the past 1 year. She had an ejection systolic murmur in the aortic area radiating to the carotids. She had multiple skin xanthomas over her feet, knees, hands and buttocks (figure 1). Echocardiography revealed severe calcific aortic stenosis (figure 2). Her serum lowdensity lipoprotein (LDL) was $391 \mathrm{mg} / \mathrm{dL}$, while triglycerides were normal. Her father and brother also had very high LDL levels and a few xanthomas

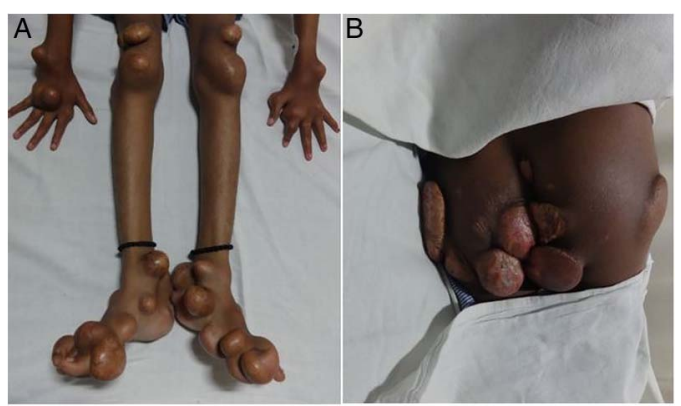

Figure 1 Multiple skin xanthomas over hands, feet, knees (A) and buttocks (B). but no features of aortic stenosis. Her mother and two sisters had normal LDL levels. The patient was thus diagnosed as having heterozygous familial hypercholesterolaemia (FH). Coronary angiography revealed plaques in the left anterior descending artery but no significant stenosis (figure 3). The aortic root was severely calcified causing valvular stenosis along with supravalvular stenosis at the sinotubular junction (figure 4 and video 1). The patient underwent successful aortic valve replacement with aortic root enlargement. Histopathological examination of the valve showed lipid deposition and calcification in the aortic cusps. She was put on high-dose statins and ezitimibe post surgery. $\mathrm{FH}$ is an autosomal dominant disorder in which the defect lies in the LDL receptor gene. Incidence is approximately $1: 500$ and 1:1000 000 in its heterozygous and homozygous forms, respectively. ${ }^{1}$ Affected individuals develop early coronary artery disease and severe aortic root calcification, despite optimisation of therapy. Previous studies have demonstrated 2.6-16\% prevalence of supravalvular and/or valvular stenosis in patients with heterozygous $\mathrm{FH}^{2}{ }^{3}$ This case describes an extremely rare presence of both the lesions together in a patient with heterozygous $\mathrm{FH}$ with characteristic skin lesions.
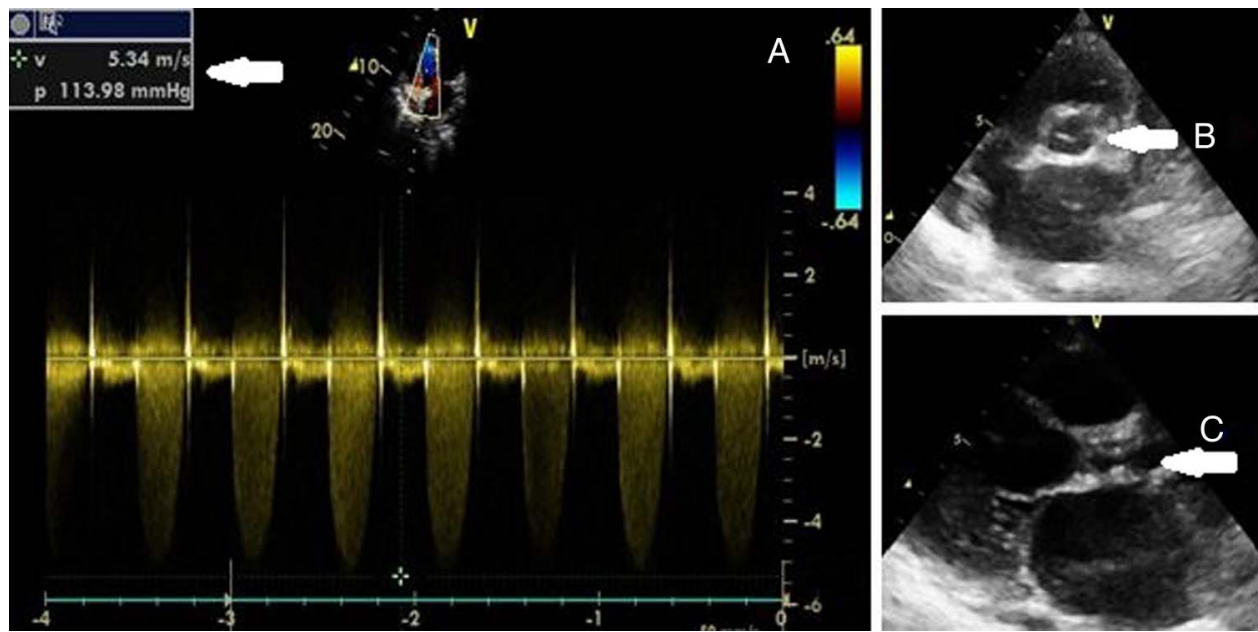

Figure 2 Echocardiogram showing a very high gradient across the aortic valve (A). Note the severely thickened and calcific aortic valve and aortic root (B and C). 
Figure 3 Coronary angiography revealing mild disease (plaquing) of proximal and mid-LAD but no significant stenosis (A-C). Left circumflex is normal. Aortic root angio showing normal right coronary artery (D). Note calcification of aortic root, outlined by multiple arrows (D).
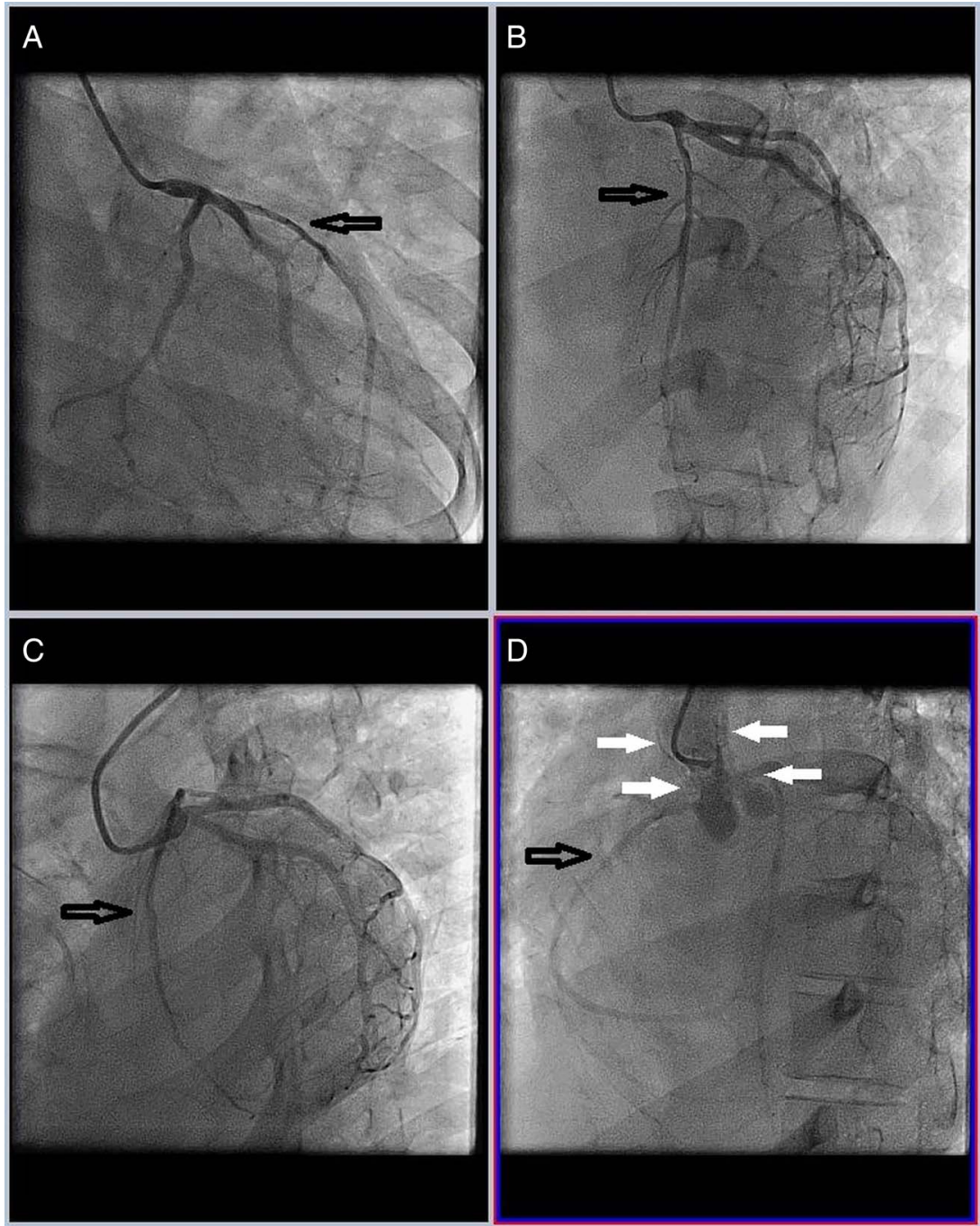

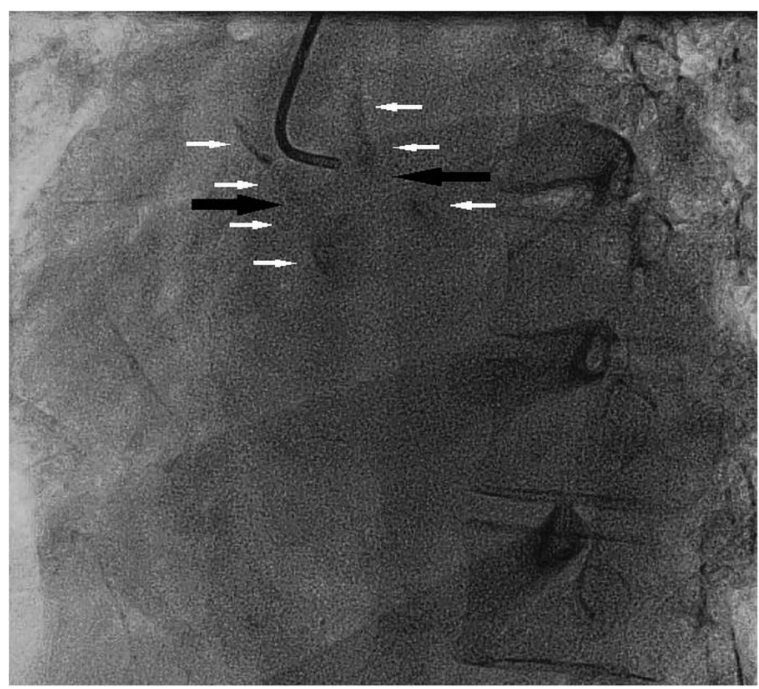

Figure 4 Heavily calcified aortic root (outlined by multiple white arrows) and narrowing at the level of the sinotubular junction (marked by black arrows) suggestive of supravalvular stenosis.

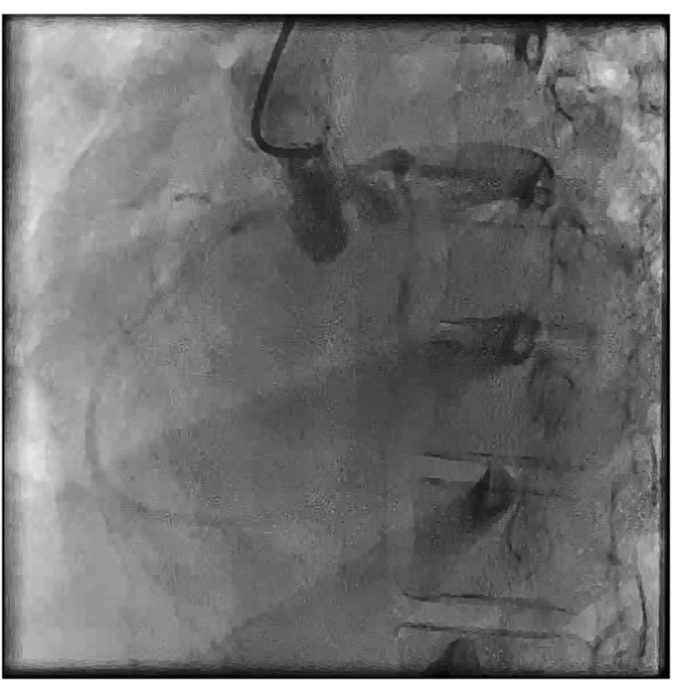

Video 1 Aortic root angiography showing calcification of the aortic root and coronary arteries, and level of supravalvular stenosis. 


\section{Learning points}

- Heterozygous familial hypercholesterolaemia is a disorder caused by mutation in the low-density lipoprotein (LDL) receptor gene, and is characterised by high-serum LDL levels and skin xanthomas.

- Premature coronary involvement and valvulopathy are common.

- Simultaneous occurrence of supravalvular in addition to valvular stenosis in heterozygous familial hypercholesterolaemia is extremely rare.

- Early recognition is warranted to achieve optimal treatment results.
Competing interests None declared.

Patient consent Obtained.

Provenance and peer review Not commissioned; externally peer reviewed.

\section{REFERENCES}

1 Civeria F. Guidelines for the diagnosis and management of heterozygous familial hypercholesterolemia. Atherosclerosis 2004;173:55-68.

2 Beppu S, Minura Y, Sakakibara $H$, et al. Supravalvular aortic stenosis and coronary ostial stenosis in familial hypercholesterolemia: two-dimensional echocardiographic assessment. Circulation 1983;67:878-84.

3 Rallidis L, Naoumova RP, Thompson GR, et al. Extent and severity of atherosclerotic involvement of the aortic valve and root in familial hypercholesterolemia. Heart 1998;80:583-90.

Copyright 2016 BMJ Publishing Group. All rights reserved. For permission to reuse any of this content visit http://group.bmj.com/group/rights-licensing/permissions.

BMJ Case Report Fellows may re-use this article for personal use and teaching without any further permission.

Become a Fellow of BMJ Case Reports today and you can:

- Submit as many cases as you like

- Enjoy fast sympathetic peer review and rapid publication of accepted articles

- Access all the published articles

- Re-use any of the published material for personal use and teaching without further permission

For information on Institutional Fellowships contact consortiasales@bmjgroup.com

Visit casereports.bmj.com for more articles like this and to become a Fellow 